\title{
IMPACT OF JUTE RETTING ON NATIVE FISH DIVERSITY AND AQUATIC HEALTH OF ROADSIDE TRANSITORY WATER BODIES: AN ASSESSMENT IN EASTERN INDIA
}

\author{
Dipankar Ghosh'1, Jayanta Kumar Biswas' \\ 1 Department of Ecological Engineering and Environmental Management, University of Kalyani, Kalyani, West \\ Bengal, India, e-mail: biswajoy2000@yahoo.com
}

Received: 2015.07.16

Accepted: 2015.08.31

Published: 2015.10.01

\begin{abstract}
Roadside transitory water bodies being manmade depressions have a great ecological and socio-economic importance from years. The effects of agricultural runoffs, jute retting, macro-phytes infestations and inadequate rainfall in changed climate often degrade transitory water bodies' environment while the biodiversity have impacted severely because of population pressure, over exploitation and indiscriminate use of fine meshed fishing gears as a whole. Physico-chemical and biological analysis with fish species composition, relative abundance, diversity indices like species richness, evenness and Shannon-Wiener index were carried out for pre-, during and post-jute retting season and for year mean as a whole to assess impact of jute retting on the roadside transitory water body's environmental health and indigenous fish diversity at Sahebnagar village in Nadia District, India. All the physico-chemical parameters barring biochemical oxygen demand and water transparency remained more or less same or marginally got little changed during those three seasons. As much as 19 native fish species with varied relative abundances and dominances were identified. Jute retting impacted lower native fish diversity indices like Shannon-Wiener index values (1.94 to 2.68) clearly indicated poor to moderate pollution status of the transitory water body in that area during monsoon in particular and throughout the year in general. So we opined there should be some control over the intense jute retting in the road side transitory water bodies for sustainable management of these manmade resources.
\end{abstract}

Keywords: transitory water bodies, physico-chemical analysis, fish diversity, Shannon-Wiener index, jute retting.

\section{INTRODUCTION}

Roadside transitory water bodies (TWB), manmade artificial depressions, have a great ecological and socio-economic importance from years. The effects of agricultural runoffs, jute retting, macro-phytes infestations and inadequate rainfall in changed climate often degrade TWBs' environment while the biodiversity in TWBs have impacted severely because of population pressure, over exploitation and indiscriminate the use of fine meshed fishing gears as a whole. The ecological, social, economic, and cultural values and functions of TWBs include: playing a key role in supporting the diversity and abundance of plants and animals, and providing important habitat and refuges for many migratory, rare or threatened species; being an essential part of natural hydrological cycles, providing water passage and storage, and may be contributing to flood mitigation and the recharge of aquifers; purifying water by stripping nutrients and intercepting sediments; making a significant contribution to the economic productivity of the State by providing essential water sources for agricultural, rural and industrial uses, vital breeding, nursery and harvest sites for edible fish, mollusks and crustaceans, brood stock for aquaculture, and areas of pasture for stock; featuring significantly in the day-to-day 
living of rural peoples; contributing to the wellbeing of people through landscape diversity and aesthetic appeal; and featuring strongly in the local tourism and recreation appeal [1].

The role of TWBs in a healthy environment has traditionally been poorly understood. Many TWBs have been and are being continuously modified and destroyed because of human activities. Some of the key threatening processes that affect TWBs include: draining out to provide land for agriculture or forestry; reclamation of transitory water body areas for rural development or dredge spoil placement; construction of bunds affecting the flow of water into the TWBs; storm water runoff that affects water quality as a result of siltation and from pollutants such as heavy metals, insecticides, fertilizers and sewage; construction of flood control and water conservation works affecting natural hydrology which is crucial for breeding cycles of some animals; introduction of livestock grazing around transitory water body edges causing damage to plants and to sedimentation; introduction of exotic pastures, weeds and exotic fish species to transitory water body areas; clearing of vegetation for firebreaks and other purposes; and climate change [2].

The effect of jute retting on environment and its agricultural significance were studied [3]. An investigation was carried out to find out the effect of jute retting on the physico-chemical and biological condition of water of an oxbow lake in Nadia district [4]. They stated that there is a large scale mortality of fishes due to general deterioration of water quality during the jute retting period and this becomes a factor leading to decline of natural fish population in this region of West Bengal. But no quantitative studies on impact of jute retting on fish diversity and aquatic health in roadside transitory water bodies in Nadia district in particular exist. Hence the objective of the present study is to quantify the impact of jute retting on the indigenous fish diversity and aquatic health status of a roadside TWB.

\section{MATERIALS AND METHODS}

\section{Study area}

Sahebnagar village in Tehatta-II development Block in Nadia District of West Bengal State, India, located on $23^{\circ} 47^{\prime} 59^{\prime \prime} \mathrm{N} 88^{\circ} 24^{\prime} 10.3^{\prime \prime} \mathrm{E}, 161 \mathrm{~km}$ from state capital Kolkata, $13 \mathrm{~km}$ and $5 \mathrm{~km}$ away from NH-34 road and the river Jalangi respectively is surrounded by Tehatta-II Block towards East, Beldanga-II Block towards West, TehattaI Block towards East, Kaliganj Block towards West, near Plassey. This place is in the border of the districts Nadia and Murshidabad (Figure 1).

The selected site was sampled from November, 2007 to Octobers, 2011 at $6.00 \mathrm{AM}$ during pre-jute retting season, jute retting season (when jute retting period lies normally during AugustSeptember) and post-jute retting season (nearly fortnight after the jute retting process gets over normally during late October). Water and soil quality parameters were estimated using standard methods [5].

Average values were taken. BOD was calculated by using modified in-situ method where initial DO reading was taken at $6.00 \mathrm{AM}$ and the water sample was diluted $(5,100$ and 10 times during pre-jute retting season, jute retting season and post-jute retting season period respectively) and taken in $250 \mathrm{ml}$ plastic bottle wrapped with black polyethylene to prevent photosynthesis and kept the bottle in the transitory water body environment for $24 \mathrm{hrs}$. from $6 \mathrm{AM}$ to next day 6.00 $\mathrm{AM}$ when final DO reading was taken. $\mathrm{BOD}_{1}$ was then calculated by multiplying the difference val-

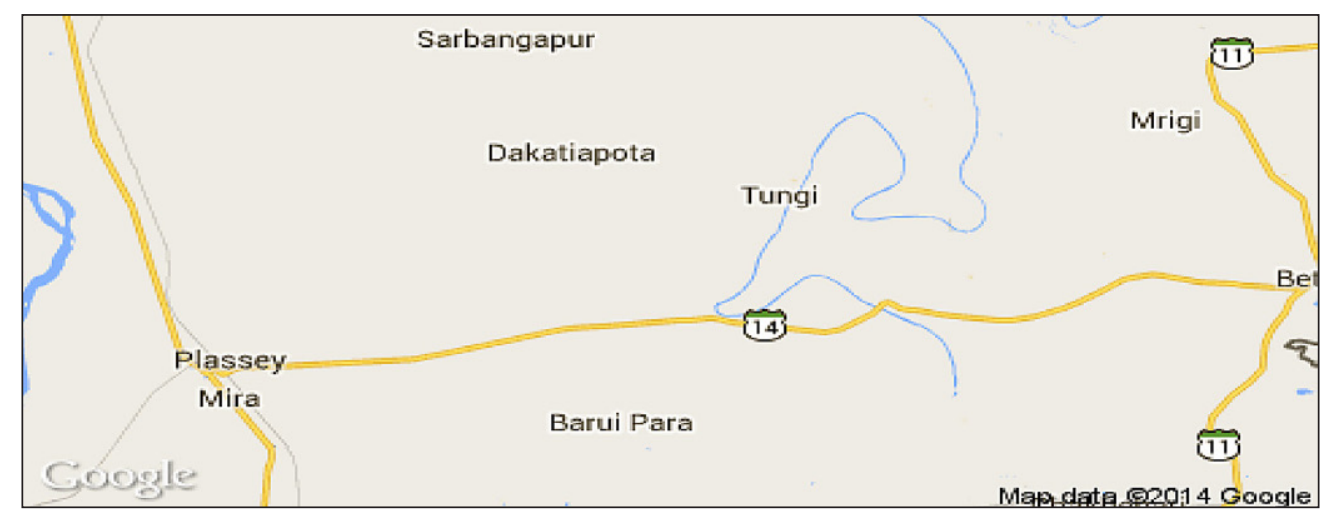

Figure 1. Sahebnagar study area marked as 14 
ue in DO level by dilution factors. This is simplified and easy field level technique of estimation of BOD which does not include photosynthesis releases of oxygen of that day and much close to reality in tropical water [6].

Fish sampling was done by using a variety of fishing gears (Table 4). After collection the fishes were identified with the help of keys prescribed by [7, 8 and 9]. The fishes were sorted out by their numbers and weighed. Fish species compositions with relative abundance during prejute retting season, jute retting season, post-jute retting season and for year period were calculated. The relative abundance (RA equaling to percentage of catch) of fish across lake was worked out for those three seasons and year. RA of individual species was calculated by dividing the product of number of samples of particular species and 100 by total number of samples. Fish species diversity subjected to diversity analysis using different indices like species richness, evenness and Shannon-Wiener index during pre-jute retting season, jute retting season and post-jute retting season and year as a whole was used to assess the roadside transitory water body's environment and fish diversity. Fish species diversity was also correlated with the physicochemical variables. Threat status of the fish species mentioned in our results was adapted from [14, 15, 16 and 17].

\section{Shannon-Wiener index}

This is a widely used method of calculating biotic diversity in aquatic and terrestrial ecosystems and is expressed as [9]:

$$
\mathrm{H}^{\prime}=\sum_{i=1}^{s} \frac{n_{i}}{n} \ln \frac{n_{i}}{n}
$$

where: $H$ - index of species diversity,

$s$ - number of species, $n_{i}$ - proportion of total sample belonging to the $i^{\text {th }}$ species.

A large $H$ value indicates greater diversity, as influenced by a greater number and/or a more equitable distribution of species. The index values ranges between 0 and 5, where higher index values demonstrates higher diversity, while low index values are considered to indicate pollution. Diversity and anthropogenic disturbances are inversely related to each other. The Shannon index takes account of species richness as well as abundance. It is simply the information entropy of the distribution, treating species as symbols and their relative population sizes as the probability. The advantage of this index is that it takes into account the number of species and the evenness of the species. The index is increased either by having additional unique species, or by having greater species evenness.

\section{Taxon evenness}

This is a relative distribution of individuals among taxonomic groups within the community) and is expressed as $E=H / \ln (R)$, where: $E$ is species evenness, $R$ is the species richness defined as the total number of distinct species in a population.

\section{RESULTS AND DISCUSSIONS}

The analysis of physical-chemical parameters (Table 1) showed almost all parameters in transitory water body located at Sahebnagar during pre-jute retting season, jute retting season and post-jute retting season periods remaining more or less the same or marginally changed, except BOD and water transparency. Table 1 and Figure 5 show variation of soil and water quality parameters in their mean values. All val-

Table 1. Physico-chemical parameters (mean values) at Sahebnagar

\begin{tabular}{|c|c|c|c|c|c|}
\hline Parameter & Pre JRS & JRS & Post JRS & Year Mean & SD \\
\hline Soil pH & 6.80 & 7.70 & 7.20 & 7.33 & 0.35 \\
\hline Water pH & 7.80 & 8.70 & 8.60 & 8.24 & 0.35 \\
\hline Transparency (cm) & 40.56 & 13.64 & 35.87 & 29.01 & 11.91 \\
\hline Temperature $\left({ }^{\circ} \mathrm{C}\right)$ & 35.50 & 29.00 & 16.50 & 24.43 & 8.06 \\
\hline DO in ppm & 3.80 & 1.90 & 3.50 & 3.11 & 0.89 \\
\hline $\mathrm{BOD}_{1}$ in ppm & 14.80 & 144.78 & 20.62 & 59.17 & 55.16 \\
\hline Hardness in ppm & 101.46 & 97.88 & 98.26 & 94.37 & 4.81 \\
\hline Alkalinity in ppm & 138.84 & 141.56 & 140.12 & 140.65 & 1.35 \\
\hline
\end{tabular}


ues do not show much variation in all seasons except of water transparency and $\mathrm{BOD}_{1}$ which are in much demoted and elevated conditions respectively. Variations in biochemical oxygen demand (BOD) of roadside transitory water body show an elevated steep during jute retting season period as compared to pre- or post-jute retting season periods (Figure 4). Mean value of $\mathrm{BOD}_{1}$ got almost 10 times increased during the jute retting season over pre-jute retting season period at TWB near Sahebnagar implying heavy jute retting intensity in that area during the season. Mean $\mathrm{BOD}_{1}$ value also got 7.25 times decreased in post-jute retting season period within 15-20 days time after the jute retting processes got over in the TWB. The water transparency (refers to the extent of solar light penetration into the water depth) mean values showed sharp fall by $22-27 \mathrm{~cm}$ during jute retting season from pre- and post-jute retting season in TWB, indicating high total solids concentration due to heavy organic matter load restricting light penetration into transitory water body indicating decrease in oxygen production due to photosynthesis. This is obviously due to heavy and huge jute retting processes in the pit during jute retting season. High values of $\mathrm{BOD}_{5}$ associated with anoxic conditions and low community diversity of fish, shell fish were the outstanding feature of the coconut husk retting zones in Kerala back water [11]. Jute retting makes the cemented tank water body near neutral by lowering the $\mathrm{pH}$ of water and there is a reduction in bicarbonate alkalinity

Table 2. Seasonal changes in relative abundances (RA \%) of native fish species

\begin{tabular}{|c|c|c|c|c|c|c|c|c|c|c|}
\hline \multirow{2}{*}{$\begin{array}{l}\text { Native/indigenous } \\
\text { fish species }\end{array}$} & \multirow{2}{*}{$\begin{array}{l}\text { Local } \\
\text { name }\end{array}$} & \multirow{2}{*}{$\begin{array}{c}\text { NBFGR \& } \\
\text { IUCN } \\
\text { threat status* }\end{array}$} & \multicolumn{2}{|c|}{$\begin{array}{l}\text { Pre JRS } \\
\text { RA } \%\end{array}$} & \multicolumn{2}{|c|}{$\begin{array}{l}\text { JRS } \\
\text { RA } \%\end{array}$} & \multicolumn{2}{|c|}{$\begin{array}{l}\text { Post JRS } \\
\text { RA \% }\end{array}$} & \multicolumn{2}{|c|}{$\begin{array}{l}\text { Year } \\
\text { RA \% }\end{array}$} \\
\hline & & & nos & wt & nos & wt & nos & wt & nos & wt \\
\hline Carp (Labeo rohita) & Rohu & LC & 6.56 & 19.12 & - & - & 8.70 & 9.96 & 7.34 & 16.77 \\
\hline Carp (Catla catla) & atla & NE & 4.92 & 12.24 & - & - & 4.35 & 4.55 & 5.50 & 11.98 \\
\hline Carp (Cirhinus mrigala) & Mrigal & LC & 9.84 & 26.69 & - & - & 8.70 & 14.74 & 10.09 & 22.88 \\
\hline Dwarf Gourami (Colisa fasciata) & Khalse & LC & 6.56 & 3.76 & 8.00 & 3.70 & - & - & 5.50 & 2.68 \\
\hline Barb (Pethia spp) & Punti & LC & 9.84 & 3.61 & 4.00 & 1.30 & - & - & 6.42 & 1.61 \\
\hline Magur (Clarias batrachus) & Magur & LC & 3.28 & 3.47 & 8.00 & 19.64 & 8.70 & 6.50 & 4.59 & 4.45 \\
\hline Singhi (Heteropneutes fossilis) & Singhi & VU & 4.92 & 3.37 & 8.00 & 16.70 & 17.39 & 6.82 & 6.42 & 2.90 \\
\hline Snakehead (Channa punctatus) & Lata & LRnt & 1.64 & 2.70 & 8.00 & 5.68 & 21.74 & 35.66 & 7.34 & 13.21 \\
\hline Koi (Anabas testudineus) & Koi & DD & 4.92 & 2.58 & 4.00 & 3.79 & 4.35 & 3.79 & 3.67 & 1.82 \\
\hline Murrel (Channa striatus) & Shol & LRnt & 1.64 & 6.24 & 12.00 & 25.61 & 4.35 & 8.91 & 2.75 & 9.82 \\
\hline Tangra (Mystus tengara) & Tangra & VU & 6.56 & 2.07 & 4.00 & 12.87 & - & - & 3.67 & 0.61 \\
\hline Chanda(Chanda nama) & Chanda & LC & 6.56 & 1.44 & 40.00 & 1.43 & - & - & 3.67 & 0.42 \\
\hline Killifish (Apolocheilus panchax) & Kanpona & $\mathrm{DD}$ & 19.67 & 0.96 & - & - & - & - & 20.18 & 0.89 \\
\hline Sarpunti (Pethia sarana) & Sarpunti & VU & 3.28 & 3.67 & - & - & - & - & 1.83 & 1.08 \\
\hline $\begin{array}{l}\text { Freshwater eel (Monopterus } \\
\text { cuchia) }\end{array}$ & Kunche & DD & 1.64 & 4.50 & 4.00 & 9.29 & - & - & 1.83 & 5.28 \\
\hline $\begin{array}{l}\text { Green eel (Macrognathus } \\
\text { pancalus) }\end{array}$ & Pankal & NT & 1.64 & 2.25 & - & - & 13.04 & 8.08 & 3.67 & 2.92 \\
\hline Zebra Danio (Danio rerio) & Zebrafish & NT & 1.64 & 0.48 & - & - & - & - & 0.92 & 0.14 \\
\hline Goby (Glossogobius giuris) & Bele & LC & 3.28 & 0.48 & - & - & - & - & 1.83 & 0.14 \\
\hline Puffer fish (Tetradon cutcutia) & Potka/Tepa & NT & 1.64 & 0.39 & - & - & 8.70 & 0.99 & 2.75 & 0.39 \\
\hline Total & & & 100.00 & 100.00 & 100 & 100.00 & 100.00 & 100.00 & 100 & 100.00 \\
\hline
\end{tabular}

* Threat status adapted from [14, 15, 16 and 17]; LRnt - lower risk near threatened, LC - least concern, NE - not evaluated, DD - data deficient, EN - endangered, NT - near threatened, VU - vulnerable, JRS - jute retting season.

Table 3. Seasonal variations in native fish diversity index

\begin{tabular}{|c|c|c|c|c|c|c|c|c|}
\hline \multirow{2}{*}{ Fish diversity index } & \multicolumn{2}{|c|}{ Pre JRS } & \multicolumn{2}{|c|}{ JRS } & \multicolumn{2}{|c|}{ Post JRS } & \multicolumn{2}{|c|}{ Year } \\
\hline & Nos & wt & Nos & wt & Nos & wt & Nos & wt \\
\hline Species richness & 19 & 19 & 10 & 10 & 10 & 10 & 19 & 19 \\
\hline Shannon-Wiener index & 2.68 & 2.37 & 1.94 & 1.98 & 2.16 & 1.97 & 2.70 & 2.31 \\
\hline Evenness & 0.91 & 0.80 & 0.84 & 0.86 & 0.94 & 0.86 & 0.92 & 0.78 \\
\hline
\end{tabular}


Table 4. Gears and crafts used in experimental fishing

\begin{tabular}{|r|l|l|c|l|}
\hline SI & \multicolumn{1}{|c|}{ Type } & \multicolumn{1}{|c|}{ Description } & Local name & \multicolumn{1}{c|}{ Attribute } \\
\hline 01 & Chinese Dip net & Lift net & Dhenki Jaal & Mesh size: 6-12 mm \\
\hline 02 & Gill net & $\begin{array}{l}\text { Made of monofilament set across breadth of canal } \\
\text { receiving water inflow during jute retting season }\end{array}$ & Fansh Jaal & $\begin{array}{l}\text { Mesh size: more than } \\
22 \mathrm{~mm}\end{array}$ \\
\hline 03 & Drag net & Seine net & Chat jal & Mesh size:6-12 $\mathrm{mm}$ \\
\hline 04 & Bamboo trap & Conical type, box type & Bitti & Fixed type \\
\hline 05 & Spear & Handy gear & Koch & Piercing fish \\
\hline 06 & Angle & Fitted with or without wheel & Chhip / Borshi & Luring fish \\
\hline 07 & Country boat & Wooden craft & Nauka & Length $5 \mathrm{~m}$ \\
\hline 08 & Dingi & Craft made of tin & Dingi & Easy movement \\
\hline
\end{tabular}

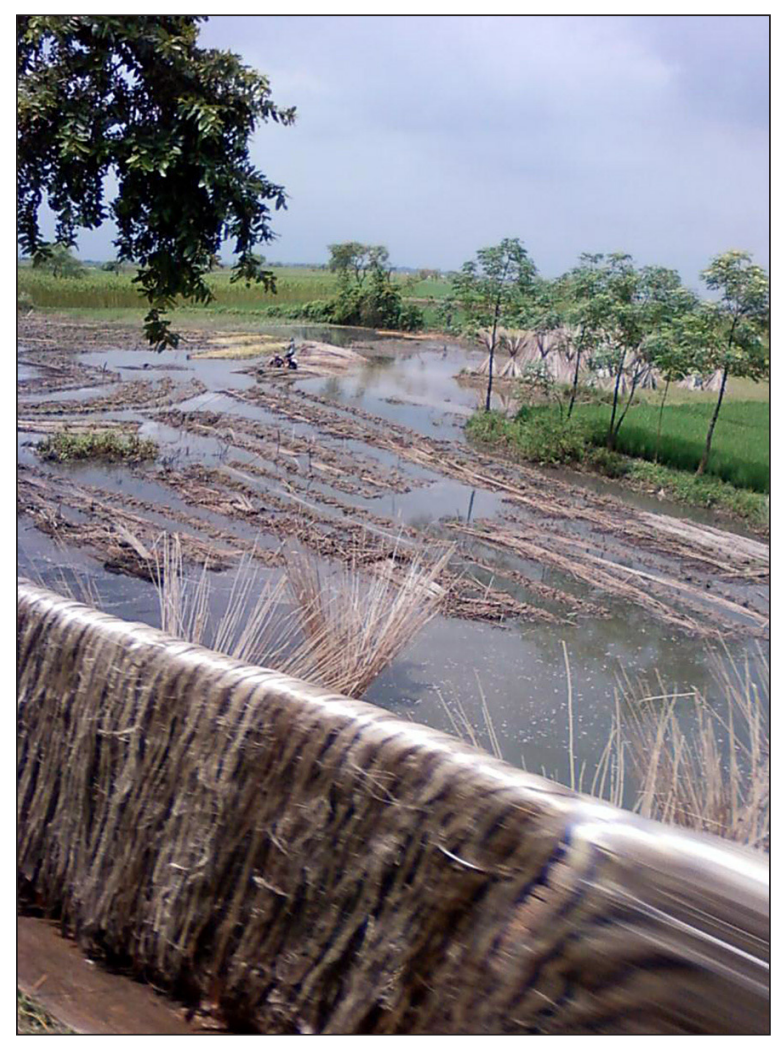

Figure 2. A view of TWB near Sahebnagar choked with intense jute retting during jute retting season

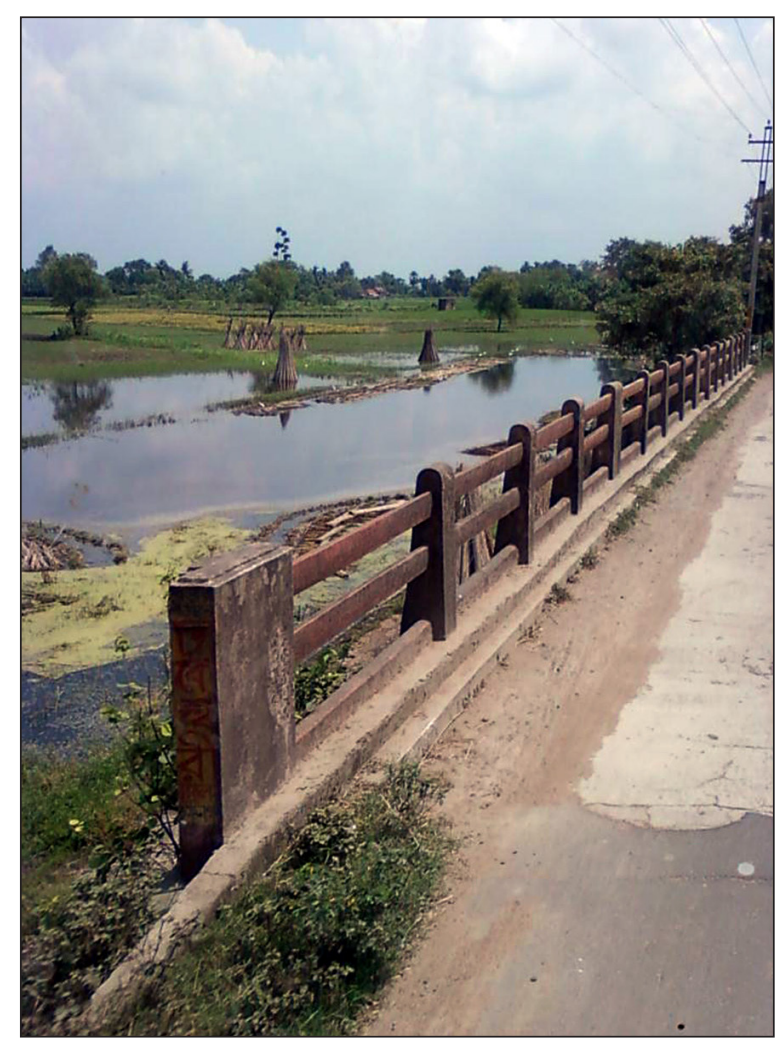

Figure 3. A view of TWB near Sahebnagar during post-jute retting season period

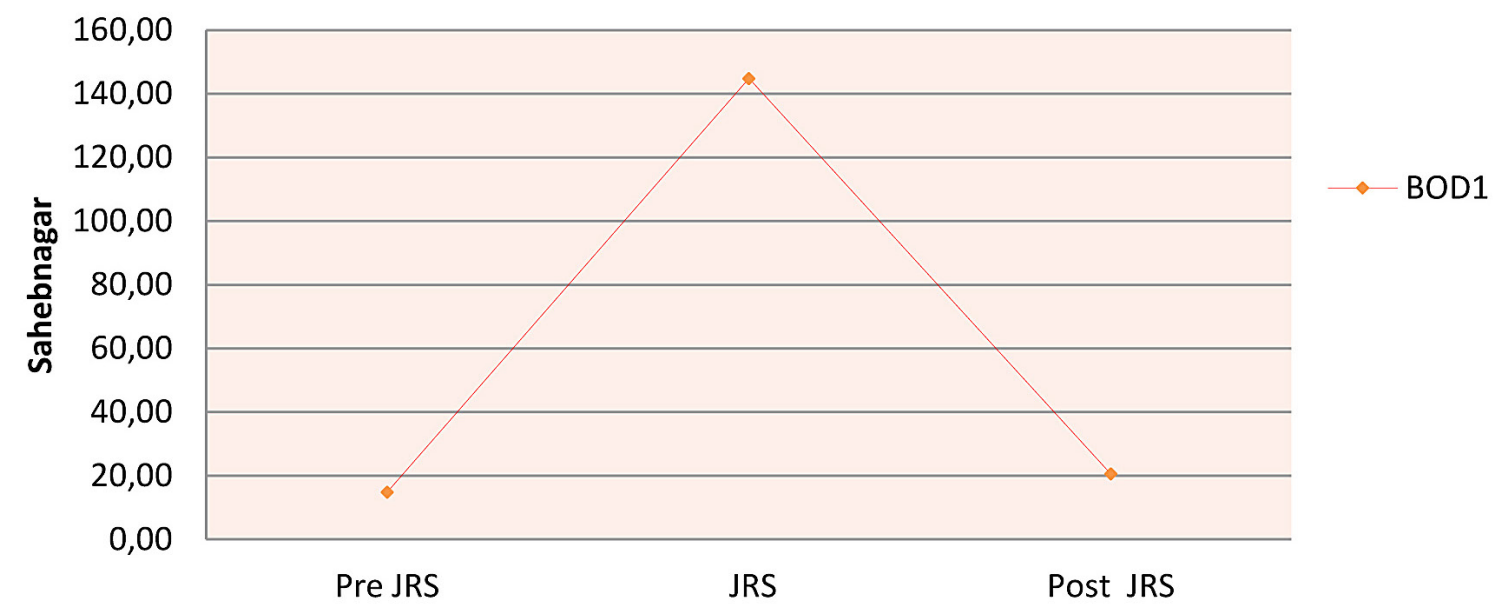

Figure 4. Fluctuations in biochemical oxygen demand (BOD) 


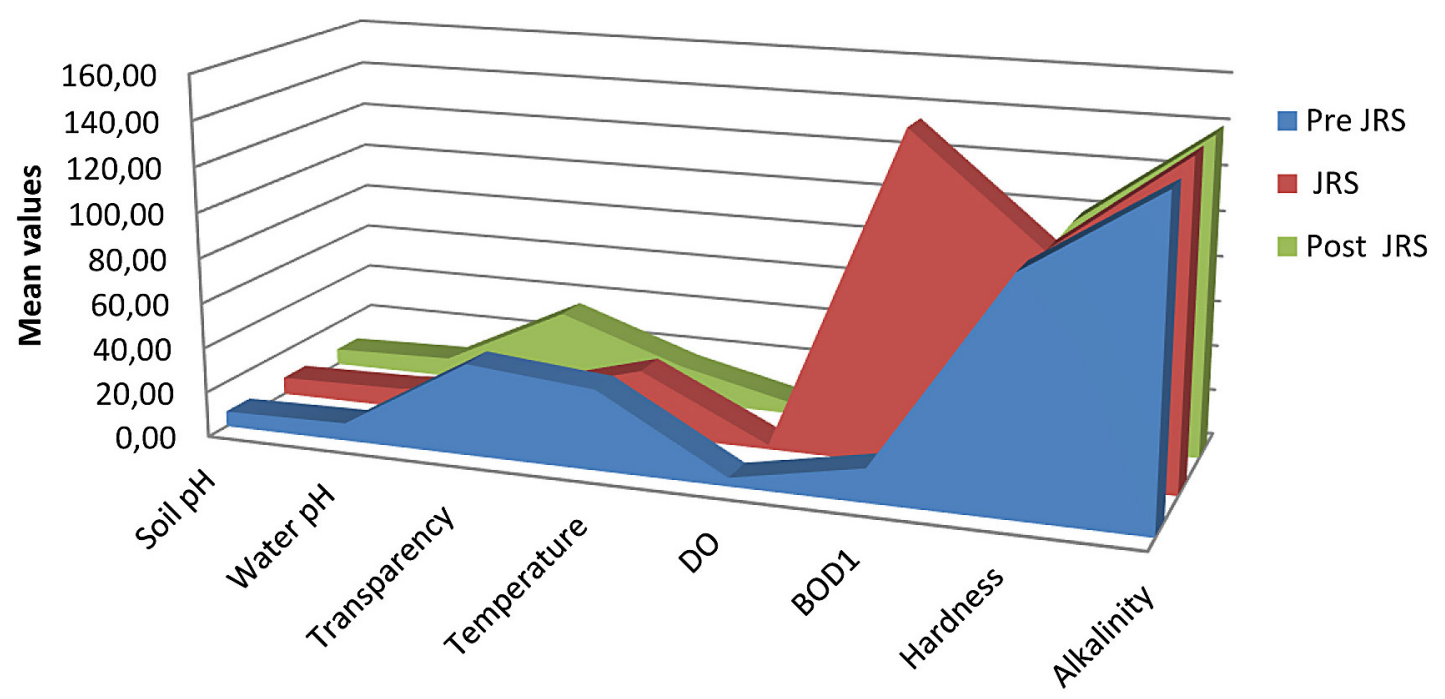

Figure 5. Variation of soil and water quality parameters

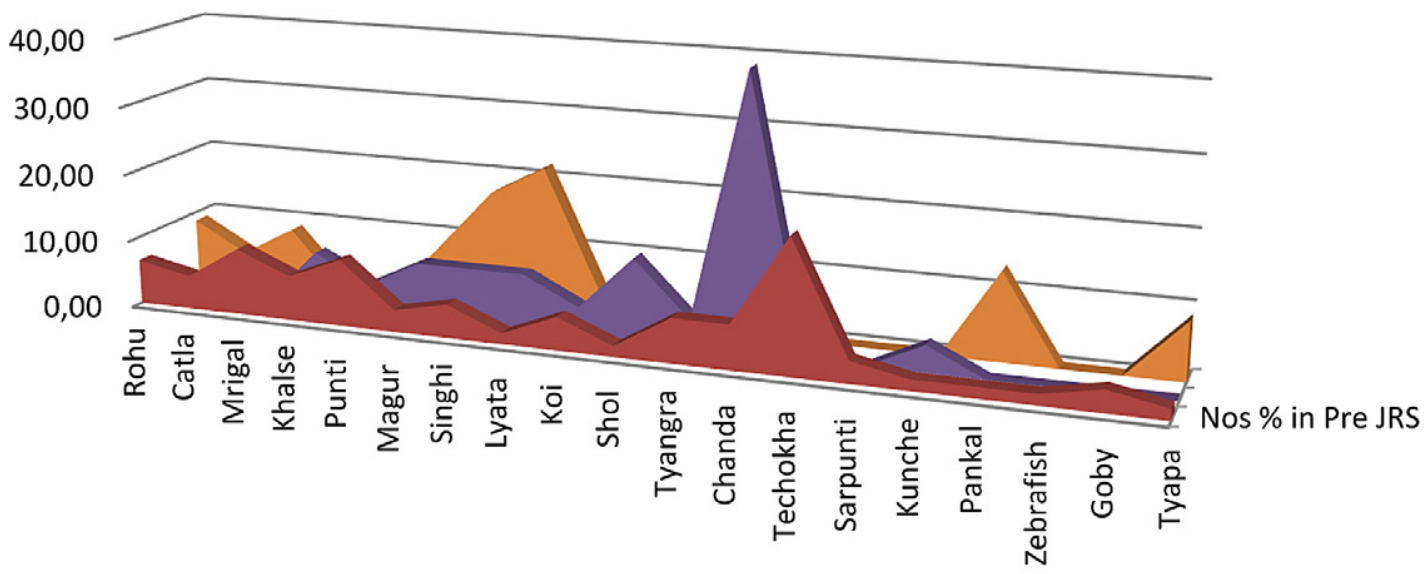

nos \% in Pre JRS $\square$ Nos \% during JRS $\quad$ Nos \% in Post JRS

Figure 6. Indigenous fish species fluctuation in percentage of numbers

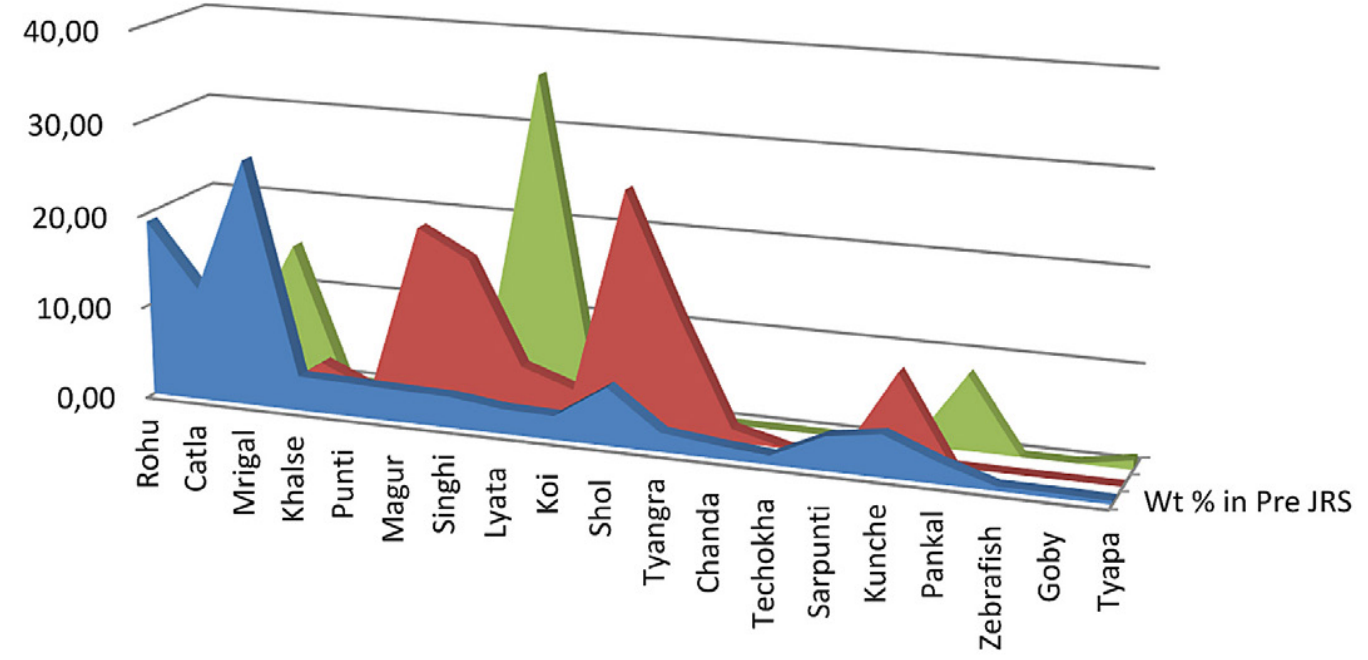

$\square \mathrm{Wt} \%$ in Pre JRS $\square \mathrm{Wt} \%$ during JRS $\square \mathrm{Wt} \%$ in Post JRS

Figure 7. Indigenous fish species fluctuation in percentage of biomass 


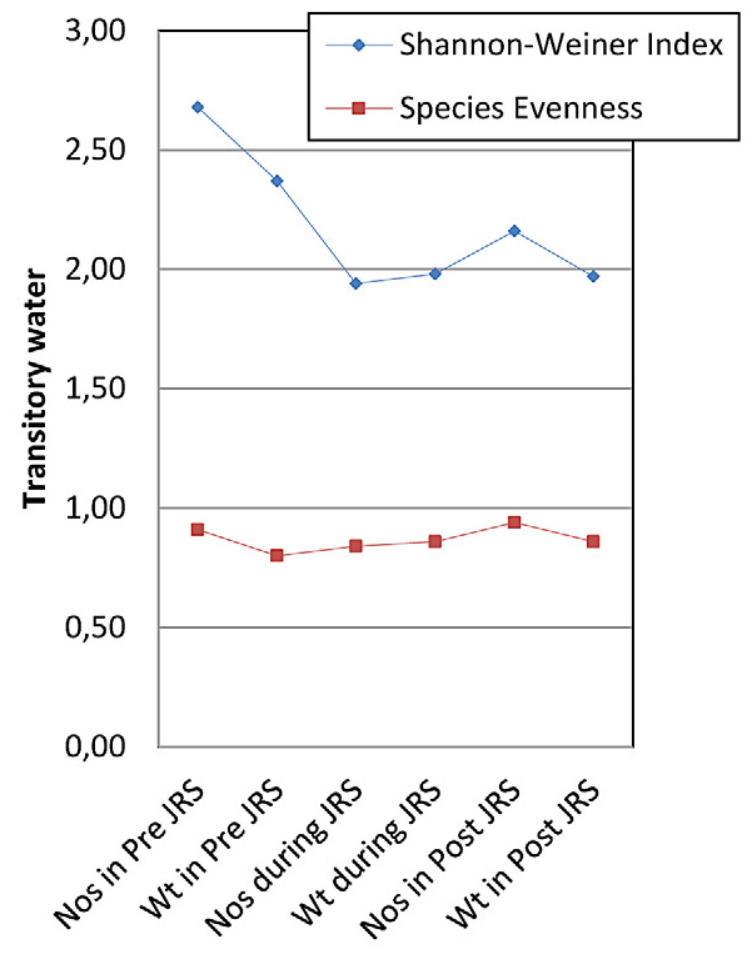

Figure 8. Flactuations of indigenous fish diversity index

as observed by [3]. According to them due to jute retting, water becomes richer in nutrients useful for aquatic flora and fauna.

No significant variation in the physic-chemical parameters except for the increase of COD and $\mathrm{BOD}_{5}$ for a short period when fish mortality was observed by [4]. They concluded that jute retting had both detrimental and favorable effect on the aquatic system. For a short period it creates an anaerobic condition and there may be fish mortality if the retting is done in a small closed water body. But with the passage of time the nutrients released from the body decaying jute, help the growth of the aquatic life. Acidic $\mathrm{pH}$ in post retting pond water sample than pre retting sample and lower observation of hardness in the post retting season were noticed by [12] with a conclusion that jute retting pose problem to pisciculture.

Table 2 and Figures 6 and 7 depicted comparisons of different fish species compositions in their relative abundance (RA \%) in numbers and biomass in the roadside water body near Sahebnagar area. Killi fish (Apolocheilus panchax) in numbers and Carp (Cirhinus mrigala) in biomass dominated the table during pre-jute retting season. Chanda (Chanda nama) and Murrel (Channa striatus) dominated in numbers and in biomass

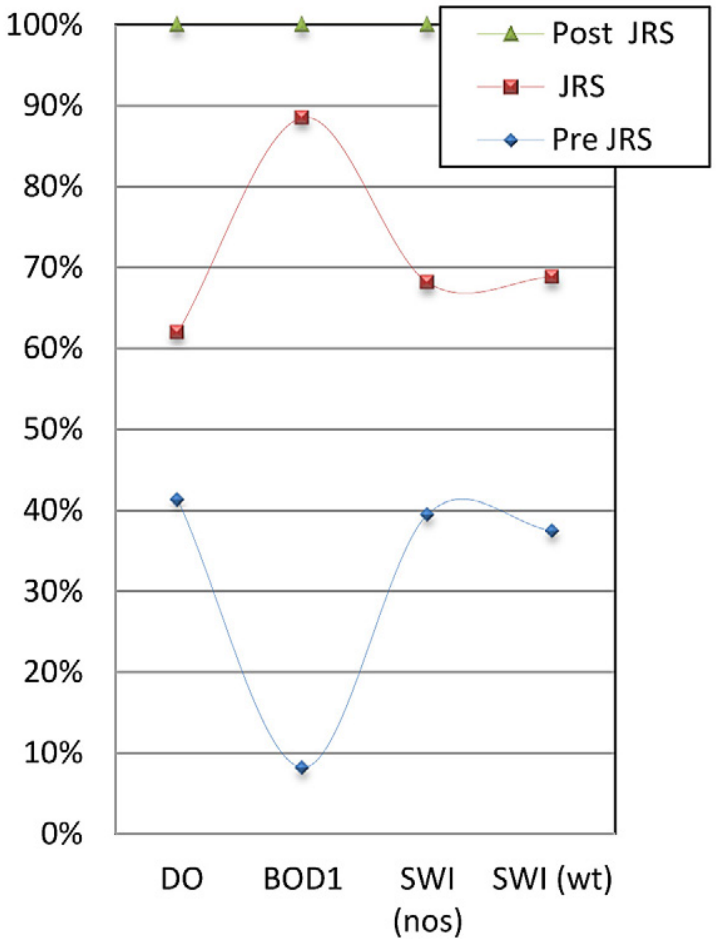

Figure 9. Variations in fish diversity index with mean values of $\mathrm{DO}$ and $\mathrm{BOD}$

respectively during jute retting season while the snakehead (Channa punctatus) led both in numbers and biomass during post-jute retting season. Table 3 furnishes fish diversity indices like species richness, evenness and Shannon-Wiener index during those three seasons of the transitory water body roadside.

Comparisons of fish species diversity index of numbers and biomass during all the three seasons are shown in Figure 8. Species richness of 19 slashed down to 10 during the retting period. High Shannon-Wiener diversity index (2.68, 2.37) of indigenous fish (for both numbers and biomass) was seen during just before jute retting season began compared to other two seasons (Figure 8) and jute retting period observed the lowest (1.94). It shows sharp deeps in Shannon-Wiener index of both numbers and weight during jute retting season. Evenness (numbers) values also showed the lowest (0.84) during this season. There was a gradual increase in fish species evenness of biomass from pre- to post-jute retting season period while a sharp decrease in evenness of numbers was observed during jute retting season in the transitory water body. Almost similar values of Shannon-Weiner index (2.4-3.0) and evenness (0.6-0.9) were observed by [13]. Figure 9 attempted a correlation of fish 
diversity index with mean values of physicochemical variables of dissolved oxygen and biochemical oxygen demand in the roadside transitory water body during pre-jute retting season, jute retting season and post-jute retting season.

\section{CONCLUSIONS}

In conclusion jute retting impacted lower diversity indices like Shannon-Wiener index values indicated poor to moderate pollution status of the transitory water body in the area during monsoon in particular and throughout the year in general. So it is opined that there should be some control over the intense jute retting in the road side transitory water bodies for sustainable management of these manmade resources. This study will be reference archive for examining the impact of jute retting on aquatic health status and indigenous fish diversity of roadside TWB in the region of Nadia district. The findings from the study will definitely benefit the planning and management of sustainable fisheries and conservation of these manmade resources at state level.

\section{Acknowledgements}

The authors acknowledge the Directorate of Fisheries, Govt of West Bengal, India for availing Block Fisheries Laboratory facilities.

\section{REFERENCES}

1. Lambert A. 2003. Economic valuation of wetlands: an important component of wetland management strategies at the River Basin Scale. (www.ecosystemvaluation.org, accessed on 22-06-2015).

2. Chakraborty T.R. 2009. Management of haors, baors, and beels in Bangladesh. Lessons for Lake Basin Management, 1-15.

3. Saha M.N., Saha A.R., Mandal T.C. 1999. Effect of jute retting on environment and its agricultural significance. Environment and Ecology, 17(3), 585-587.

4. Dasgupta M., Goswamy S., Goswamy A. 2006. Effect of jute retting on the physic-chemical and biological condition of water. Indian Journal of Fisheries, 53(4), 455-457.
5. American Public Health Association (APHA), 1998. Standard methods for the examination of water and wastewater. 20th ed. Clesceri LS, Greenberg AE, Eaton AD, (Eds), American Public Health Association, Washington, DC.

6. Selvaraj G.S.D. 2005. Assessment of Biochemical Oxygen Demand (BOD) in tropical aquatic systems (modified). CMFRI special publication mangrove ecosystems: A manual for the assessment of biodiversity, 83, pp. 201.

7. Datta Munshi J.S. and Srivastava M.P. 1988. Natural history of fishes and systematics of freshwater fishes in India. Narendra Publishing House, New Delhi, pp. 421.

8. Talwar P.K. and Jhingran A.G. 1991. Inland fishes of India and adjacent countries. Oxford and IBH Co. Pvt. Ltd., New Delhi, Vol. I-II, pp. 1158.

9. Jayaram K.C. 1999. The freshwater fishes of the indian region. Narendra Publishing House, New Delhi, pp. 551.

10. Shannon C.E. and Wiener W. 1949. The mathematical theory of communication. University of Illinois Press, Urbana, USA, 117.

11. Nandan S. Bijoy 1997. Retting of coconut husk - a unique case of water pollution on the South West coast of India. International Journal of Environmental Studies, 52(1-4), 335-355.

12. Das B., Tripathy S., Chakraborty A., Chakrabarti K. 2011. Studies on physico-chemical and microbiological parameters of water samples before and after Jute Retting. Journal of Biological Sciences, 11(2), 201-215.

13. Basavaraja D., Narayana J., Kiran B.R., Puttaiah E.T. 2014. Fish diversity and abundance in relation to water quality of Anjanapura reservoir. Karnataka, India. Int. J. Curr. Microbiol. App. Sci. 3(3), 747-757.

14. Lakra W.S. and Sarkar U.K. 2007. Freshwater fish diversity of central India. Edited and published by National Bureau of Fish Genetic Resources, Lucknow, pp. 1-183.

15. Lakra W.S/, Sarkar U.K/, Gopalakrishnan A., Kathirvelpandian A. 2010. Threatened fresh water fishes of India. Published by National Bureau of Fish Genetic Resources (NBFGR).

16. IUCN 2011. IUCN Red List of Threatened Species. Version 2011.2 (http://www.iucnredlist.org/ apps/redlist/search).

17. IUCN 2015. The IUCN Red List of Threatened Species. Version 2015.2 (http://www.iucnredlist. org/search, accessed on 23-07-2015). 